Katerina

Kolozova

\title{
Metaphysics of Finance Economy: Of its Radicalization as the Method of Revoking Real Economy
} Real Economy

Katerina Kolozova is professor of philosophy and gender studies at the Institute of Social Sciences and Humanities-Skopje and University American CollegeSkopje. She is the author of The Cut of the Real: Subjectivity in Poststructuralist Philosophy published by Columbia University Press in 2014

\section{Abstract}

My claim here is that there is no exit from metaphysics. We are metaphysical creatures inasmuch as we are material, the latter always already inviting the former. However, an exit from the disciplining and hallucinatory grasp of philosophical metaphysics or from philosophy is possible, as both Marx and Laruelle have shown. The effects of such exit will not only be intellectual or academic, but also social. Philosophical decisionism in an absolute form is the essence of capitalist economy and politics, and I will try to demonstrate this further on. Nonetheless, the ideas of political system or the possibilities of thinkable political horizons remain or become ever more detached from the economic logic of the liberal, pseudo-materialistic and individualist philosophy of exploitation through alienation called capitalism.
If "giving up our abstractions" (Marx) is the central and most important task of the science Marx invents and attempts to institute, then, I would argue, the follow up task should be to emancipate the metaphysics that is the object of that science from the authority of philosophy. It is the primitive and radical metaphysics of the inevitable gesture of mediating the immediate real that ought to be salvaged through non-philosophical, scientific operation with the chôra of metaphysical thought. Economic emancipation and other important forms of social emancipation would only follow consequentially. I would sum up Marx's project as follows: its central task is to overcome the underlying and essentially philosophical alienation which enables the dichotomies of state politics and civil society, of the "spiritual" or religion and the secular, of "use value" and "surplus value." Finally, the task of Marxist science is to serve to a political struggle which seeks to overcome the phantomal existence shaped by wage labor and surplus value. The universe ruled by surplus value is guided by the impulse to suffocate real life and its material grounding represented as use value.

To radicalize metaphysics is to render it transcendental in the last instance, to acknowledge it as the necessary mediator or the core of radical subjectivity or what Laruelle terms "the Stranger." The subject establishes a 
relation of exteriority to $i^{1}$ and, seen in its last instance (or radically and inalienably), ${ }^{2}$ it is the Stranger at the heart of the human-in-human. This concept admits and affirms the dyad between the real, the lived (or "le joui sans jouissance") of the human in the last instance and the subject, while remaining radically descriptive or minimally transcendental. ${ }^{3}$ The affirmation of the dyad engenders the radical subjectivity or the "figure of the Stranger," 4 as explained in the previous chapter. The sense of pain created by the original and necessary estrangement and the sense of appropriation of this pain which transmutes the painful lived into joy, the sense of possession or of being at home, i.e., the sense of inalienable belonging, with the Stranger emerging from the heart of our mute self is the most immediate form of radical metaphysics.

My claim here is that there is no exit from metaphysics. We are metaphysical creatures inasmuch as we are material, the latter always already inviting the former. However, an exit from the disciplining and hallucinatory grasp of philosophical metaphysics or from philosophy is possible, as both Marx and Laruelle have shown. The effects of such exit will not only be intellectual or academic, but also social. Philosophical decisionism in an absolute form is the essence of capitalist economy and politics, and I will try to demonstrate this further

1 François Laruelle, Théorie des Etrangers: Science des hommes, démocratie et non-psychanalyse, Paris: Éditions Kimé, 1995), 196.

2 Laruelle, Théorie des Etrangers: Science des hommes, démocratie et non-psychanalyse, 196: " 'Radical' ne signifie pas autre chose qu'inaliénable ou que « de-dernière-instance.»

3 Larulle, Théorie des Etrangers, 221-223.

4 Francois Laruelle, Théorie des Étrangers: Science des hommes, démocratie et non-psychanalyse (Paris: Éditions Kimé), 1995, 164-166 on. Nonetheless, the ideas of political system or the possibilities of thinkable political horizons remain or become ever more detached from the economic logic of the liberal, pseudo-materialistic and individualist philosophy of exploitation through alienation called capitalism.

Philosophical entrapment of metaphysics is constituted by the so-called amphibology of "the being" and the real, ${ }^{5}$ of "essence" and "the being." I would like to propose a non-philosophical procedure of radicalizing metaphysics - through unilateralizing the dyad - by way of situating it in the "material self" as its subject. Through the necessary and radical estrangement, or, in Laruelle's terms, through the emergence of the figure of the Stranger at the core of the real or of the human-in-human, the inception of the metaphysical is constitutive of every subjectivization. This inception is painful, nonetheless inevitable and always already in place without being the product of a philosophical intention. Radicalizing metaphysics would result into furnishing the grounds for a realist or non-philosophically materialist theory of the human universe. The radical dyad is at the heart of the material self which has trouble claiming its own self as its own. Affirming the dyad means affirming the real of the trauma it produces. It also means affirming its reality instead of erasing it through a second gesture which is always philosophical (which, of course, includes religion and in particular Abrahamic theologies).

\section{The source of the capitalist drive: dispossession rather than possession}

The sense of alienation begins at the level of subject's constitution and it is this sense of dispossession that begets the grounding anxiety which creates philosophy

5 A Laruellian term, explained in the previous chapters. 
as a panic and totalitarian response to it. Capitalist hyper-production of "added value" (added to the surplus value) represents a total colonization of society and material life by philosophy as the totalitarian response to a metaphysical need. Let us reiterate, this metaphysical need is materially grounded. The hysteria of private possession and of possessing the truth (of the real) as if it were the real itself aims to compensate for this primordial sense of dispossession. Can the problem of primordial dispossession be solved through the gesture of erasing it and, if done so, wouldn't that be a properly philosophical response? So, is the abolition of the desire for any form of possession or property the true goal of communism seen as the result of the non-philosophical science Marx attempts to establish? If alienation created through wage labor represents exacerbation of the sense of grounding dispossession, capitalism is certainly not the solution to it, in spite of its ceaseless compulsion to be precisely that.

Therefore, a sense of possession is not what defines capital and the capitalist self but rather insatiable urge for it originating in the grounding dispossession. The capitalist drive creates an unstoppable process of alienation of labor, of objectifying human labor and the suffering behind it. Numeric or speculative value of pleasures or sources of pleasure (measured in money) derives from the urge toward ever greater perfection through abstraction of the needs that are only in their last instance material. In short, the founding operation of capitalist society is the procedure of dispossession of the material from its own metaphysical transposition (for example, of the worker from her metaphysics of work, of the lover from his metaphysics of pleasure). The cancelling of radical or primitive metaphysics is the defining prerequisite of philosophical and capitalist metaphysics.
At the beginning of the 21st century, economy is no longer economy in the proper sense of the word. It is an instrument of finances which postures as economy in its own right. "Finance industry" establishes amphibology with the real economy linked to material production of material consumables (a term explained below). The purely symbolic, linguistic (insofar as a matter of signification) value of money is no longer added to the material or use value. It is utterly detached from it. It has become auto-referential and its value is measured only according to hypothetical measurements in hypothetical systems of measuring. According to The Financial Crisis Inquiry Report published by the US Government in 2011, ${ }^{6}$ the great financial crisis which began in 2008 (and in 2013, it seems, it is here to stay), or the "recession," was the result of "wrong estimations of the ranking agencies and the banks" about: the worth of "derivatives," "securities" and other forms of derivation of financial value from another financial value and with no direct reference to any real or physical property or use value. (Indirectly and in the last instance, after a virtually endless line of mediations, there is always reference to an estimation of the worth of a material property.) The authors of the Report write:

In the years leading up to the crisis, too many financial institutions, as well as too many households, borrowed to the hilt, leaving them vulnerable to financial distress or ruin if the value of their investments declined even modestly. For example, as of 2007, the five major investment banks-Bear Stearns, Goldman Sachs, Lehman Brothers, Merrill Lynch, and Morgan Stanley-were operating with extraordinarily thin capital. By one measure, their leverage ratios were as high as 40 to 1 ,meaning for every $\$ 40$ in assets, there

6 The Financial Crisis Inquiry Report published by the US Government in 2011, pp. xix-xx. 
was only $1 \$$ in capital to cover losses. Less than a $3 \$$ drop in asset values could wipe out a firm. To make matters worse, much of their borrowing was shortterm, in the overnight market-meaning the borrowing had to be renewed each and every day. For example, at the end of 2007, Bear Stearns had 11.8 billion in equity and $\$ 383.6$ billion in liabilities and was borrowing as much as70 $\$$ billion in the overnight market. It was the equivalent of a small business with $\$ 50.000$ in equity borrowing $\$ 1.6$ million, with $\$ 296750$ of that due each and every day. One can't really ask "What were they thinking?" when it seems that too many of them were thinking alike. And the leverage was often hidden-in derivatives positions, in off-balance-sheet entities, and through "window dressing" of financial reports available to the investing public. ${ }^{7}$

Evidently what was traded was not the material value (or the use value) of a material or physical object, together with its estimated surplus value. Only the surplus value entered into exchange after it had become completely detached from reference to and relevance of any use value. Negligence and squander of the real value of mortgages, or the fact that their real financial value had been unchecked or falsified, was not the main reason for "the collapse of the financial system" in 2008. The possibility of an utterly speculative trade, one based on pure abstractions of values and complete detachment from the material (reflected in use value) is the generator of the problem. Moreover, it represents the very foundation of investment banking and the "investment business" as a form of economy. As we can see in the paragraph quoted above, the "investment economy" is not based on capital in the classical sense of the word. It is not based on capital even in the financial sense which implies its translatability into the material. Its

$7 \quad$ The Financial Crisis Inquiry Report, $\mathrm{xx}$. foundations lie in the "thin air" of its capacities to rank, estimate, evaluate, predict, create and control processes in the financial market.

There is nothing material in the 21st century form of capitalism. Contemporary capitalism is not only based on "immaterial labor," as Negri and Hardt claim, ${ }^{8}$ but also on pure abstraction and elevation to immateriality of both labor and capital. This situation is the result of the complete mathematization and speculation of the real. The 662 pages of the Financial Crisis Inquiry Report to the US Government (quoted above) display the blatant truth that concept itself (and all of its possible realities) of the "investment banking" is indiscernible from the so called "shadow banking system." In the last instance it is speculative and while speculating it interprets the material according to its own immanent rules (of speculation) and is in no way bound by the "primitive real." The real which has not been transformed into a meaning, signification or value is the "primitive," unruly real that seems to be non-existent unless given shape and value by the speculative mind. Investment banking, in the last instance, is determined by the practice of conducting "expertise" and speculation about the immaterial value (surplus or financial value) behind - or derived from material worth. ${ }^{9}$

8 Michael Hardt and Antonio Negri, Multitudes: War and Democracy in the Age of Empire (Penguin Putnam), 2004.

9 The Financial Crisis Inquiry Report, 27-28: First, we describe the phenomenal growth of the shadow banking system-the investment banks, most prominently, but also other financial institutions-that freely operated in capital markets beyond the reach of the regulatory apparatus that had been put in place in the wake of the crash of 1929 and the Great Depression. This new system threatened the once-dominant traditional commercial banks, and they took their grievances to their regulators and to Congress, which slowly but steadily removed long-standing restrictions and helped banks break out of their 
Capitalism is grounded in fetishization, wrote Marx. Contemporary economy is, in the last instance, determined by fetishism. The term fetishization in Marx may be borrowed from the studies of religion he was familiar with at the time when he was writing the first volume of Capital, but its meaning is very precise in terms of understanding the split between use value and surplus value, and also how the latter necessarily engenders the very logic of money as capital.

$\mathrm{M}-\mathrm{M}$ '. We have here the original starting-point of capital, money in the formula $\mathrm{M}-\mathrm{C}-\mathrm{M}^{\prime}$ reduced to its two extremes $M-M^{\prime}$, in which $M^{\prime}=M+D M$, money creating more money. It is the primary and general formula of capital reduced to a meaningless condensation. It is ready capital, a unity of the process of production and the process of circulation, and hence capital yielding a definite surplus-value in a particular period of time. In the form of interest-bearing capital this appears directly, unassisted by the processes of production and circulation. Capital appears as a mysterious and self-creating source of interest the source of its own increase. The thing (money, commodity, value) is now capital even as a mere thing, and capital appears as a mere thing. [...] The social relation is consummated in the relation of a thing, of money, to itself. Instead of the actual transformation of money into capital, we see here only form without content. As in the case of labour-power, the usevalue of money here is its capacity of creating value - a value greater than it contains. Money as money is potentially self-expanding value and is loaned out as such - which is the form of sale for this singular commodity. ${ }^{10}$

traditional mold and join the feverish growth. As a result, two parallel financial system of enormous scale emerged.

10 Karl Marx, Capital Vol. III Part V, Chapter: Externalization
If capitalism is determined in the last instance by what Marx calls "fetishism," and if the latter is determined as speculative (hence, philosophical), ${ }^{11}$ it is bound to end up (and also - end) as "financial economy," understood in opposition to "real economy" (the distinction is discussed below). By way of instituting the "fiat money" principle at its very origins, the possibility of an economy unattached to any material or use value (or in some economic vocabularies "objective value") has been introduced. Moreover, speculation and, therefore, detachment from the real are the determination in the last instance and the vector of capitalist economy.

\section{Pure speculation as the determination in the last instance of capitalism as philosophy}

The defining detachment from use value produces and sustains a defining relevance of the pretension that the speculative logic of economy determines or engineers the use value itself. The implication is, therefore, that direct and material needs can be subsumed under fetish based needs. The desire is disciplined by the capitalist jouissance and it operates upon the physical attempting to mold it. As language governs the body, as philosophy governs the real so the "speculative needs" are more urgent than the material ones. A philosophy as the world or the world as philosophy, specifically defined

of the Relations of Capital in the Form of Interest-Bearing Capital (First English edition of 1887 with modernisationof spelling; Moscow: Progress Publishers, 1959), available at https://www.marxists.org/archive/marx/works/1867-c1/, accessed on 17 October 2014.

11 As explained in the previous chapters, Marx equates philosophy with the abstract or the metaphysical (even when it is defined as "materialistic"), and it is difficult to determine if he seems any intrinsic possibility for it to detach itself from the metaphysical determination in the last instance. 
by capitalism, is what sustains these processes and maintains capital's circulation of significance.

The philosophical/capitalist mirror of desires and needs falls asunder when confronted by the material urgency of the suffering bodies. Pain, hunger and rage created by the urgency of survival dispel the speculum of detached needs inscribed in the universe of "what matters in human life." When economic resources that provide for the material (and "spiritual" as used in Marx's texts) needs and interests are exhausted and survival is under threat, the speculum of capitalism and philosophy becomes "the bubble" The Financial Crisis Inquiry Report talks about.

In 2008, the bubble burst and thereupon the state intervened. The intervention could not, however, be speculative. It had to draw on the material resources of its citizens: mortgages defaulted in the US, austerity cuts introduced in the EU. The brute material had to enter the scene of finances. The material in the guise of defaulted mortgages and destroyed livelihoods provided the grounds for the resurrection of a universe of nothing but signification - finances and the speculative "finance industry." The world made of "estimation" of the material had to be saved by a holocaust of the material. In the end, it wasn't the monetary value added to the material use value and to the labor force but the sheer bricks and land and life (as labor force) and livelihood of the labor force that had to ensure the survival of the banks and the resurrection of the specter - the market of speculation. The bricks and livelihoods were destroyed as soon as they were translated into "derivatives."

The 2008 crisis was the first instance in the history of capitalism when its speculative foundation was proven untenable unless supported by matter and in the last instance determined by the real and/or the physical. Contemporary economics is the product of the philosophical determination in the last instance which postulates that the brute material is meaningless unless signified as monetary value. All ought to become pure signification since the material in itself is meaningless and worthless in the human universe which is one made of signs, exchange of signification or communication. My simplifying generalization is that, according to the ruling visions of authority today, the essence of economy or the logic market has its own intrinsic laws unattached to the basic survival needs of the human and non-human animals. In the last instance, contemporary economics is determined by the transcendental. Namely, it is determined by a philosophical decision as to what reality is, and this decision institutes itself as more real than the real itself. The transcendental postulation which constitutes its determination in the last instance is Kantian and post-Kantian. In other words, it is always already postmodern.

Capitalist vision of the world is essentially philosophical. It is a vision determined by its decisionism rather than by the authority of the real without the "added value" of philosophical or economical meaning. With this explanation of capitalism in view, I concur with the accelerationist idea of Nick Srnicek and Alex Williams, inspired by Nick Land's theory of accelerationism, according to which speeding up capitalism's functioning according to its inherent logic can be revolutionary. ${ }^{12}$ Nonetheless, acceleration itself is immanent to capitalist political economy. The sheer introduction of the gesture of acceleration to what already accelerates itself

12 “\#ACCELERATE MANIFESTO FOR AN ACCELERATIONIST POLITICS," CRITICAL LEGAL THINKING (14 MAY 2013), available at http://criticallegalthinking. com/2013/o5/14/accelerate-manifesto-for-anaccelerationist-politics, accessed on 29 january 2014. 
unstoppably does not constitute an intervention (let alone a revolution). Emancipation of the processes of acceleration from the bourgeois grip and their subsequent radical socialization (transformation into commons rather than the private property of a few individuals) are required in order to transcend capitalism and begin the creation of a socialist society.

The ever more accelerated capitalism will inevitably take its political-economic infrastructure and the specter of "finance industry" to a stage of hitting against the bedrock of the real and, as a result, to the falling asunder of its auto-referential meaninglessness. The real is not speculative, it is "the physical and sensuous" (Marx). It is the real-of-the-human which is presubjective and prelingual (Laruelle). ${ }^{13}$ Therefore, the revolts in the city squares, the sit-ins, the occupation of space, as Benjamin Noys argues, the overall slowing down and resistance to the temporal strategies of capital is one of the effective forms of resistance. ${ }^{14}$ In a parallel fashion and without establishing contradiction, another form of resistance is to accelerate the speed of speculative finance in order for it to hit against the impossibility of the real consisting in the lack of material resources. If finance industry capitalizes on the sheer ruse of projections about the worth of the material (all assets backed by material property), the absence of anything to estimate and project about will condition its end..$^{15}$ The surplus value and use value will inevitably dissociate when there are disproportionately more empty buildings than populated ones, an inflation

13 Laruelle, Ethique de l'Étranger (Paris: Éditions Kimé, 2000), 259.

14 Benjamin Noys, "The War of Time: Occupation, Resistance, Communization," Identities X 1-2 (30 October 2013), 83-92, available at http://identitiesjournal.edu.mk/cat.php?id=1.

15 Brett Scott, The Heretic Guide to Global Finance: Hacking the Future of Money (London: Pluto Press), 2013 of defaulted mortgages and devaluated assets. An apocalyptic landscape is, evidently, necessary for a new political horizon to appear. Nick Land's accelerationist nihilism could be understood also in this sense, and this is where I identify its revolutionary potential (regardless of whether Land positions himself right or left). ${ }^{16}$

The financial crisis in 2008 proved wrong the philosophical grounding of modern economy as essentially materialistic and conveyed its purely transcendental or speculative foundations. The sobering effect of the real materialized in the form of trauma caused by defaulted mortgages, lost homes and lost jobs dispelled the mathematical purity of contemporary economy as financial in its last instance. In spite of the blow of the real which burst the global financial bubble in 2008, nowadays, 8 years later, the fetish or the specter of money rules stronger than ever. Austerity cuts aim at saving speculation itself. Remorseless saving has been imposed on social strata but also on entire countries. The most prominent case in Europe is that of Greece. Real economy is practically dead because for the sake of saving and returning a debt of fiction: "interest rates," estimations of the worth of estimation (money). Real economy is dying in the name of the industry of production of signification or value. Finance industry is now alive and well, in perfect detachment from the material or use worth, whereas the material resources are progressively impoverished, and, in the end, will be destroyed. The vampirism of finance industry and its political elites is sucking out the life of all that is living on this planet. The exploitation and destruction of nature which includes the human race - leaves us with a spectral universe which will soon be inhabitable for its vampires

16 Nick Land, Fanged Noumena: Collected Writings 19872007, edited by Ray Brassier and Robin McKay (Faltmouth: Urbanomic), 2011 
too. Currently, the real is suppressed by the (essentially capitalist) universe of speculation in the philosophical sense, but also in the sense of the speculative mind of gaming. ${ }^{17}$

\section{Economy is always already political}

Gaming includes risk. But the type of gaming which grounds the so-called finance industry does not presuppose risk in the last instance, i.e., material defaulting and materially - or physically and really experienced loss. In the last instance, when the gamers collided with the rock of the real - the material threat to "their way of life" - they asked for a government bailout and they got it. Apparently, there is direct complicity between banking industry and the government, at least in the US and in the European Union, as it has been proven since 2008. Intervention of the state in the affairs of economy of the kind which produces use value (apart from or in addition to the surplus value) is understandable. However, the motivation of the state to intervene in the so-called finance industry in order to save it and maintain economic stability is utterly vague. How does the stability of the investment banks and funds serve the general economic stability, the one linked to material production, consumption and sustainability?

17 The Financial Crisis Inquiry Report published by the US Government (2011), 48: Herb Sandler, the co-founder of the mortgage lender Golden West Financial corporation, which was heavily loaded with option ARM loans, wrote a letter to officials at the Federal Reserve, the FDIC, the OTS, and the OCC warning that regulators were "too dependent" on ratings agencies and "there is a high potential for gaming when virtually any asset can be churned through securitization and transformed into a AAA-rated asset, and when a multi-billion dollar industry is all too eager to facilitate this alchemy.
Investment banking concerns investments into investments, betting on the viability of investments and selling those speculations to other investment speculators. They serve all sorts of funds whose activity comes down to the trade of their assessment, of their best guess or speculation about of the financial worth of something which has only indirect or meditated - if any - material worth. The material determination in the last instance is not the subject of trade in investment banking and is hardly its determination in the last instance.

In the last instance, investment (and/or banking) industry has no effect on the real industry. At least, not a productive one. So, why is the maintaining of the stability of the finance market so important for the economic stability of a country? How come it is more important than the "material industry" or the so called real economy? This question departs from the fact that the bailout of the former takes place at the detriment of the latter. ${ }^{18}$

Regardless of the eventual presence/absence of oversight, government intervention was required and considered legitimate since it is a government's responsibility to

18 The Financial Crisis Inquiry Report, 60: This resilience led many executives and regulators to presume the financial system had achieved unprecedented stability and strong risk management. The Wall Street banks' pivotal role in the Enron debacle did not seem to trouble senior Fed officials. In a memorandum to the FCIC, Richard Spillenkothen described a presentation to the Board of Governors in which some Fed governors received details of the banks' complicity "coolly" and were "clearly unimpressed" by analysts' findings. "The message to some supervisory staff was neither ambiguous nor subtle," Spillenkothen wrote. Earlier in the decade, he remembered, senior economists at the Fed had called Enron an example of a derivatives market participant successfully regulated by market discipline without government oversight. 
preserve economic stability of a country (and through that of all other forms of social stability). This means that the use value necessary for life, both physical and "spiritual" (as in Marx's texts, i.e., as attached and directly issuing from the physical) survival of the ordinary citizens, had to be transformed into surplus value that serves the stability of the financial market. In other words, the material is annulled by transforming it into the purely speculative, the use value is barred by its total transformation into surplus value and the sole purpose of this process is to sustain a universe of pure surplus value.

How important is the health of the investment and banking industry, how important is the health and the stability of hedge funds and insurance companies for the survival of the so called real economy? How has the crisis of the investment industry really affected the material production of tangible use value? If banking industry can be viewed as an industry in its own right which can remain fundamentally detached from the real economy, how important is it for a country's stability to insure the survival and preservation of this autonomous universe? The crisis has certainly affected all those whose houses have been defaulted or who have lost social benefits. If that is the case, then, the US Government's bailout of the big investors brought more than danger than stability to its society and, hence, economy: a) growth of poverty, b) a huge hole in the national budget, and c) preservation of an "industry," which not only does not necessarily support the real economy, but, quite to the contrary, immanently contains the tendency to destroy it (the real economy) if it brings more profit to it. ${ }^{19}$

19 Michael Schroeder et al., "The Role of Investment Banking for the German Economy: Final Report for Deutsche Bank AG, Frankfurt/Main,” Mannhelm: Zentrum für Europäische Wirtschaftsforschung, 2011, p. 12
This is one attempt at explaining the phenomenon of "financialization of economy." Let us examine what other possible definitions there are.

\section{The change of Marx's equation}

Investment banks do not serve the final beneficiaries of any real economy, i.e., humanity and other living beings. Since the dawn of capitalism until the emergence of "finance economy," industry has been producing material goods. Its goal has always been the surplus value, it vector has always been M_M1, however always and by definition grounded in the production of commodity, the hybrid of use value and surplus value. Use value has been the indispensible intermediary in the creation of surplus value. That is the logic behind the equation M-C-M (money-commodity-money).

At the turn of the 21st century, investment banking assumed the status of the unavoidable intermediary for the investors' main activity (making profit). With the usurpation of the status of the main intermediary in investing, banking industry has suppressed and, finally, eliminated production of use value as the central intermediary for achieving the defining capitalist goal (represented by the M-C-M equation). Since investment or finance industry has assumed the status of an industry in its own right and its speculative activities have been assigned the quality of products exchanged on the market, Marx's M-C-M has turned into M-M-M. Commodities produced by the apparently self-sufficient industry of banking are purely financial phenomena because they originate in the register of speculation which produces pure signification - money. Commodities produced by the banking industry bear the names of: securities, derivatives, certificates, bonds, equities, etc. The M-M-M cycle is detached from the material, from 
the primary, secondary and tertiary economy which continues to satisfy the material needs of the human and non-human animals. The chasm that has appeared between the universe of sheer speculation (M-M-M) and that of the physical world and its immediate needs (to which M-C-M was still somehow related) will grow. Finally, the foundering of the image, and of the tenuous reality of the economic whole the two are presumed to constitute, will become inevitable.

When in 2008 financial crisis or recession was declared, the US government decided that the financial institutions facing bankruptcy were "too big to fail," since that would have destabilized the entire economy considering they were "too interconnected with other financial institutions." ${ }^{{ }^{20}}$ But would such eventual failure have affected the real economy, in all of its three sectors? Considering investment banks are detached from commercial banks and work practically with no capital, as the US Financial Crisis Inquiry Report informs the reader (quotes are provided above), exactly how would the eventual failure of banking industry have affected the production of the real economy?

In a study entitled "The Impact of the Financial Crisis on the Real Economy," the authors state: "The cost of the financial crisis to the real economy has so far remained underexamined, probably because of the difficulty in making such an assessment." ${ }^{21}$ This study, which is a policy analysis of the financial crisis' effects on the European and, more particularly, German economy, makes apparent the fact that the impact of the financial market on the "real market economy" remains a "rather vague phenomenon.” It is not only vague to the authors of the study but also to the other academic and nonacademic authorities in the area cited in it.

Hartmann-Wendels et al. (2010, p. 23), for instance, considerthelegalterm „Finanzdienstleistungsinstitute“ the German equivalent of investment banks. According to the legal definition of the functions of financial service providers ("Finanzdienstleistungsinstitute", $\S 1 \mathrm{a}$ KWG), however, the term is rather broad as it also includes other financial service providers besides investment banks. Another issue is raised by the assignment of some financing activities closely intertwined with investment banking activities (e.g. financing of M\&A transactions). Although in practice such financing activities may be considered a part of investment banking, the widespread definition of investment banking in academic literature refrains from assigning any financing functions to the term investment banking. Hartmann-Wendels et al. (2010, p. 16) define investment banking as the set of "all functions of a bank, which support trading at financial markets." 22

In his book from 2013 "Profiting Without Producing," Costas Lapavitsas claims the same and he explains that the notion of "financialization of economy" never even entered the vocabulary or the conceptual apparatus of mainstream economics. Nonetheless, the phenomenon has been determining our economic realities since 2008 . ${ }^{23}$ Lapavitsas' book also demonstrates how the neoliberal economy is essentially enabled by "monopoly state control over the final means of payment."

\footnotetext{
22 Ibid. 12.

23 Costas Lapavitsas, Profiting Without Producing: How Finance Exploits Us All (London/NY: Verso, 2013),
} 
The fact that the role of the "finance economy" was completely unexamined at the time when the Crisis was declared did not prevent the US government to react with bank bailouts as it did not prevent the EU governments to react with budget cuts and other forms of state intervention aiming to preserve "economic stability." What was, in fact, being saved was the self-enveloped world of the financial market, a self-sufficient universe parasitizing on the rest of the society and of the economy rather than providing grounds for their survival and growth. On the other hand, the negative effects on the real economy caused by the reduced spending capacity of the population were something which could be predicted by every economist, politician and also by the ordinary citizen. Therefore, what is known to be detrimental to the economic stability and growth (material not financial or speculative) was sacrificed in the name of what is known to be utterly unexamined in terms of its effects with respect to the real economy. The states which went on to save their national and the global "financial industries" determined that the intermediary between money making and more money making was more important for the overall economic stability than the real economy.

The Enigma of Capital ${ }^{24}$ by David Harvey proffers a genealogy of the "financialization of economy" and of the financial crisis which occurred after 2007. According to the evidence presented by Harvey, deregulation of finance was the cornerstone of the "new and global financial architecture," which originated in the late 1970s, and "was accelerated in 1986 and became unstoppable 1990s." ${ }^{25}$ Harvey explains that deregulation was a political invention. It was an intervention of the neoliberal governments into the banking system aiming

24 David Harvey, The Enigma of Capital and the Crisis of Capitalism, (Oxford: Oxford University Press, 2010)

25 Harvey, The Enigma of Capital, 16. to bridge "the gap between what labor was earning and what it could spend." ${ }^{\prime 26}$ It is interesting to note that the banks were reluctant to embrace absolute liberalism and, hence, absence of any regulation. Therefore, tells us Harvey, "political pressure" had to be used in order to force financial institutions such as Fannie Mae and Freddie Mac to "loosen the credit strings for everyone." ${ }^{27}$

Costas Lapavitsas debunks the myth about the helpless states incapable of establishing control over the "out of joint capitalism" and of the imagined "elemental forces" of naturalized economy. Behind the mirage of unrestrained liberalism lies the truth of economic and social policies of nation-states. The idea of absolute liberty of the market, the imaginary of the natural forces of capital is made possible by a grounding metaphysical premise about "naturalness" of capitalist free market economy. Lapavitsas reminds us that economy has always been political, just as Marx insisted.

Second, crucial to the ascendancy of private credit money has been its legal convertability into statebacked money created by central banks. The latter is a hybrid form of money: it is partly credit since it is created through credit mechanisms (mostly lending by the central bank to private banks); it is partly fiat since it is inconvertible legal tender that normally rests on the state's promises to pay. This hybrid form of money is the ultimate lever of state power in the realm of finance because it allows the state to provide liquidity and to make payments at critical junctures. Financialization has been stamped by the conscious management of state-backed central bank money through various mechanisms of the state. Central

26 Harvey, The Enigma of Capital, 17.

27 Ibid. 
banks have emerged as a leading public institution, typically under a façade of independence. The command exercised by states over central bank money has made sustained intervention in the field of finance possible throughout the period of financialization. The importance of control over state-backed credit money was made clear in the course of the global crisis of the 2000s. ${ }^{28}$

Political pressure that needed to be used in order to install the "system of neoliberalism," proves that absolute liberty of economy and finances is not a natural, self-generated reality. Rather, it is the product of a political decision. Therefore, it is the product of philosophical decision. It relies on a postulation of reality that is essentially philosophical. This means that one not only postulates cognitively about the real, but also performs a practical gesture of philosophical intervention whereby thought determines what the real/reality is. While determining the real, the same gesture performs a second subterfuge gesture - truth substitutes reality. "Decisionism" of this sort, let us reiterate Laruelle's thesis, is what determines any and all philosophy in the last instance, thereby producing an amphibology between thought and the real. Most important product of this amphibology is "the Being." ${ }^{29}$ By that same logic, absolute freedom and its supposed innate self-regulation are creations of a philosophical decision which surreptitiously and "amphibologically" instilled itself as the real rather than what it really is - a political (and philosophical) decree.

Through the bailouts of investment banks and through the budget cuts, the state authorities have strived to preserve a self-sufficient universe of abstraction called

28 Costas Lapavitsas, Profiting Without Producing, 70.

29 François Laruelle, Philosophie et non-philosophie (BruxellesLiege: Pierre Mardaga, 1989), $42 \mathrm{ff}$. "finance industry." This universe of pure abstraction seems to be based on the original presupposition that it can survive completely detached from the real or the material world ( $=$ the world of defaulted houses and massively reduced reproduction of material goods). Is it possible that this is a philosophical flaw, result of a mere superstitious misconception? Is it possible that the origin of the crisis consists in a philosophical fallacy according to which the fetish (money) represents not just a reality but also a worth in its own right rather than mere mediation between two or more material realities? George Soros has accused the German Chancellor Angela Merkel for precisely this - a philosophical fallacy in the ways in which she has dealt with the crisis, i.e. for "misconceptions and taboos" which lead to austerity measures against the debtor Eurozone countries such as Greece. ${ }^{30}$ In a number of interviews and articles, George Soros, the person who had been one of the main proponents of "finance industry," unraveled the spectral nature of that same industry which made him rich. He termed the belief in its realness - a misconception. This point is the undercurrent in the central set of arguments in his article on the topic, published in October 2013. Let us consider the following quote:

I can testify from personal experience that investors would flock to Greece once the debt overhang was removed. But the official sector cannot write down its debt, because that would violate a number of taboos, particularly for the ECB. ${ }^{31}$

30 George Soros, “Angela Merkel's Pyrrhic Victory,” Project Syndicate VIII (7 October 2013), available at http://www. project-syndicate.org/commentary/george-soroson-angelamerkel-s-pyrrhic-victory, accessed on 30 November 2013.

31 George Soros, “Angela Merkel's Pyrrhic Victory,” available at http://www.project-syndicate.org/commentary/georgesoroson-angela-merkel-s-pyrrhic-victory, accessed on 30 November 2013. 
Certainly, one can never be sure if Merkel suffers from "misconceptions" about the nature of financial market and its allegedly immanently liberal and self-regulating nature or whether she has made an informed political decision to stick with the policies of neo-liberalism. The same dilemma stands for Barack Obama and his financial policies and political decisions related to the post 2007 crisis. In spite of Soros's advice to the contrary, in 2008, Obama decided to bailout the banks. George Soros, one of the most generous financial supporters of Obama's electoral campaign in 2008, advised Obama to nationalize the banks instead, reports the Wall Street Journal Online..$^{32}$ It appears unusual that a finance magnate would opt for nationalization of banks while a politician decides to opt for financialization of the national economy. Once again, it seems viable to claim - and, in this respect, I follow David Harvey's argument presented above - that the financialization of global economy is a political project rather than an economic "natural process."

Fictitious financial capital took control and nobody wanted to stop it because everyone who mattered seemed to be making lots of money. In the US, political contributions from Wall Street soared. Remember Bill Clinton's famous rhetorical question as he took office? 'You mean to tell me that the success of the economic program and my re-election hinges on the Federal Reserve and a bunch of fucking bond traders?' Clinton was nothing if not a quick learner. ${ }^{33}$

32 Luca Di Leo, "Soros Criticizes Obama's Bailouts," The Wall Street Journal (1 March 2010), available at http://online.wsj. com/news/articles/SB10001424052748704089904575093760 994295890, accessed on 9 December 2013.

Harvey, The Enigma of Capital, 17. Oxana
In spite of the conscious decision or the philosophical ruse to convince the world that "innate absolute freedom" of finance is natural state of affairs rather than a state's trick to postpone decisions regarding real economy (as much as possible or almost indefinitely), we might be dealing with misconceptions too. In other words, an informed political decision to pursue neoliberal policies does not exclude the possibility of uninformed misconceptions about its "realness" in the world of material production and reproduction (social, economic and physical). The idea that one could postpone material reality without material consequences is probably a misconception, a fallacy of the fundamentally speculative mind of contemporary Capital perpetuating an old metaphysical hierarchy which accords primacy and supremacy to the mental (or "the idea") over the bodily (or "the material"). 